\title{
Herbage accumulation dynamics in digit grass subjected to defoliation frequencies
}

\section{Dinâmica do acúmulo de forragem do capim faixa-branca submetido a frequências de desfolhação}

\author{
Natan Teles Cruz ${ }^{1 *}$; Braulio Maia de Lana Sousa ${ }^{2}$; Jailson Lara Fagundes²; \\ Alfredo Acosta Backes²; José Dantas Gusmão Filho ${ }^{3}$; Ricardo Teles Vilas-Bôas ${ }^{4}$; \\ Cesar Augusto Rizato ${ }^{1}$; Leandro Teixeira Barbosa ${ }^{2}$
}

\begin{abstract}
This study was undertaken to examine the herbage accumulation dynamics and structural characteristics of digit grass subjected to different defoliation frequencies in the period of January 2015 to February 2016. Four defoliation frequencies [very high $(25 \mathrm{~cm})$, high $(35 \mathrm{~cm})$, medium $(45 \mathrm{~cm})$, and low $(55 \mathrm{~cm})$ ] were evaluated in two periods of the year [greater insolation (September to March) and lesser insolation (April to August)]. The experiment was set up as a randomized-block design with four replicates. Overall, the decreasing defoliation frequencies increased the cutting interval; leaf area index; total-herbage, stem, and dead-herbage accumulation rates; and percentages of stems and dead herbage. This reduction in defoliation frequency also resulted in a lower leaf accumulation rate and percentage of leaves. In overall terms, digit grass showed higher total-herbage, leaf, and stem accumulation rates; percentages of stems and dead herbage; stem volume density; and tiller density in the period of greater insolation. In the period of lesser insolation, however, digit grass exhibited a lower dead-herbage accumulation rate and a lower percentage of dead herbage. Less frequent defoliations increase the herbage accumulation rates of digit grass, but result in a less desirable morphological composition.
\end{abstract}

Key words: Brazilian Northeast. Digitaria eriantha. Forage canopy. Pasture management.

\section{Resumo}

Este trabalho foi realizado com o objetivo de avaliar a dinâmica do acúmulo de forragem e as características estruturais do capim faixa-branca submetido a diferentes frequências de desfolhação, no período de janeiro de 2015 a fevereiro de 2016. Foram avaliadas quatro frequências de desfolhação: muito alta $(25 \mathrm{~cm})$, alta $(35 \mathrm{~cm})$, média $(45 \mathrm{~cm})$ e baixa $(55 \mathrm{~cm})$, em duas épocas do ano: maior insolação (setembro a março) e menor insolação (abril a agosto). Utilizou-se o delineamento experimental em blocos casualizados com quatro repetições. De maneira geral, a redução na frequência de desfolhação aumentou o intervalo entre cortes, o índice de área foliar, as taxas de acúmulo de forragem total, de colmos e forragem morta e as porcentagens de colmos e forragem morta. Por sua vez, esta redução

\footnotetext{
1 M.e, Programa de Pós-Graduação em Zootecnia, Universidade Federal de Sergipe, UFS, São Cristóvão, SE, Brasil. Email: teles. nc@gmail.com; rizato.cesar@gmail.com

2 Profs. Drs., Programa de Pós-Graduação em Zootecnia, UFS, São Cristóvão, SE, Brasil. E-mail: bmaiasousa@yahoo.com.br; ratinhojlf@yahoo.com.br; alfredoaab_67@yahoo.com.br; leandro@ufs.br

3 Prof. Dr., Instituto Federal de Educação, Ciência e Tecnologia de Sergipe, IFS, Glória, SE, Brasil. E-mail: dantas.zoot@hotmail. com

4 Zootecnista, UFS, São Cristóvão, SE, Brasil. E-mail: ricardo_tvb@hotmail.com

* Author for correspondence
} 
na frequência de desfolhação diminuiu a taxa de acúmulo de lâmina foliar e a porcentagem de lâmina foliar. De maneira geral, o capim faixa-branca apresentou maiores taxas de acúmulo de forragem total, de lâmina foliar e colmos, porcentagens de colmos e forragem morta, densidade volumétrica de colmo e a densidade populacional de perfilhos no período de maior insolação. Por sua vez, o capim faixa-branca apresentou no período de menor insolação menor taxa de acúmulo de forragem morta e porcentagem de forragem morta. Desfolhações menos frequentes aumentam as taxas de acúmulo de forragem do capim faixa-branca, porém com composição morfológica menos desejável.

Palavras-chave: Digitaria eriantha. Dossel forrageiro. Manejo de pastagem. Nordeste brasileiro.

\section{Introduction}

In the last decades, much research has been done with forage plants in pastoral environments. These studies have allowed for rational management recommendations to be made in Brazil based on frequencies and intensities of defoliation (SILVA; NASCIMENTO JÚNIOR, 2007). Variations in the pasture height established for the entry and exit of animals under a rotational grazing system result in distinct levels of intraspecific competition for light by the forage canopy (CARNEVALLI et al., 2006; ZANINE et al., 2011; BARBERO et al., 2015). This phenomenon can change the accumulation of herbage and its nutritional value, ultimately influencing the feeding behavior and productivity of animals grazing on these forages (PALHANO et al., 2007; VOLTOLINI et al., 2010a, b).

Those studies have been carried out with a greater emphasis on the genera Urochloa (Syn: Brachiaria), Panicum, Pennisetum, and Cynodon. However, several forage species of regional importance and which may present a significant forage value for animal production are less researched. In part, this hampers the dissemination of these species among livestock farmers due to lack of knowledge regarding their productive potential and chemical composition, especially when subjected to different defoliation frequencies.

Digit grass (Digitaria eriantha Steud. cv. Suvernola syn: Digitaria umfolozii) is a forage plant recommended for intensive pasture-based milk and meat production systems (ARONOVICH et al., 1996). At present, in Brazil, its use is more restricted to the northeast region, especially the states of Sergipe and Alagoas (SOUZA et al., 2016). This grass is adapted to grow in soils with low natural fertility (GARCÍA; PÉREZ, 2005), but is responsive to nitrogen fertilization (SOUZA et al., 2016). Additionally, this species has the ability to absorb water particles suspended in the air, which allows it to grow in regions with little rainfall (NAVARRO et al., 2005), making it responsive to irrigation (OLIVEIRA et al., 2015).

Despite its regional importance, studies involving digit grass are still rare. This creates a great demand for the evaluation of this plant with a view to generating information that help to define more-adequate management targets. Obtaining more in-depth information about the productive and structural characteristics of this grass as a function of the applied defoliation targets may increase the interest in the cultivation of this forage plant, especially in Northeast Brazil, if its forage value is validated. Therefore, understanding how digit grass responds to different management strategies throughout the year is a step of extreme importance to define adequate and rational management practices,

The present study thus proposes to evaluate the herbage accumulation dynamics and structural characteristics of digit grass subjected to four defoliation frequencies in two periods of the year.

\section{Material and Methods}

Digit grass was evaluated from January 2015 to February 2016 in an area of the Federal University of Sergipe (UFS), located in São Cristóvão - SE, 
Brazil (11 $\left.22^{\prime} \mathrm{S} ; 37^{\circ} 12^{\prime} \mathrm{W} ; 47 \mathrm{~m}\right)$. According to Köppen's classification, the climate of the region is a tropical Awa type with a dry season from September to March and a rainy season from April to August. The average annual precipitation in the region is $1,372 \mathrm{~mm}$, and the average temperature is 25.3
${ }^{\circ} \mathrm{C}$. Climatic data of the experimental period were obtained at the National Institute of Meteorology (INMET), at the meteorological station in Aracaju, which is approximately 20,000 away from the experimental area (Figure 1 and 2).

Figure 1. Average insolation and maximum, mean, and minimum temperatures from January 2015 to March 2016.

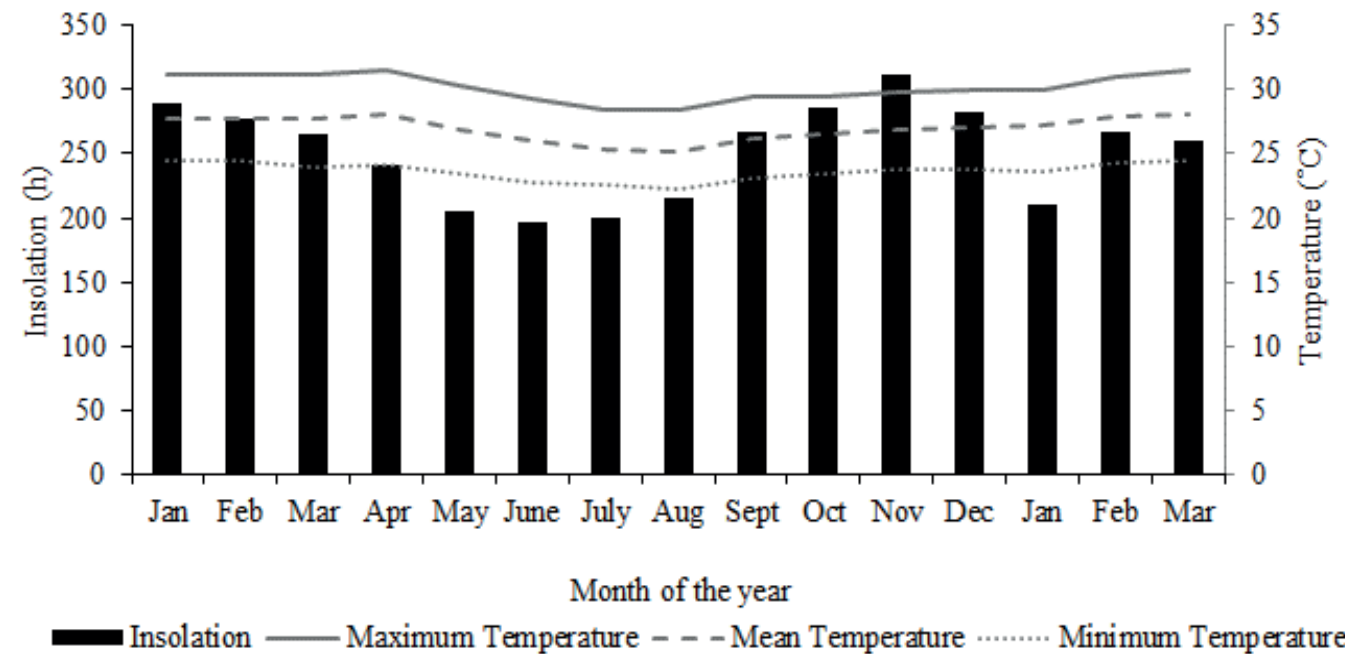

Figure 2. Average precipitation from January 2015 to March 2016.

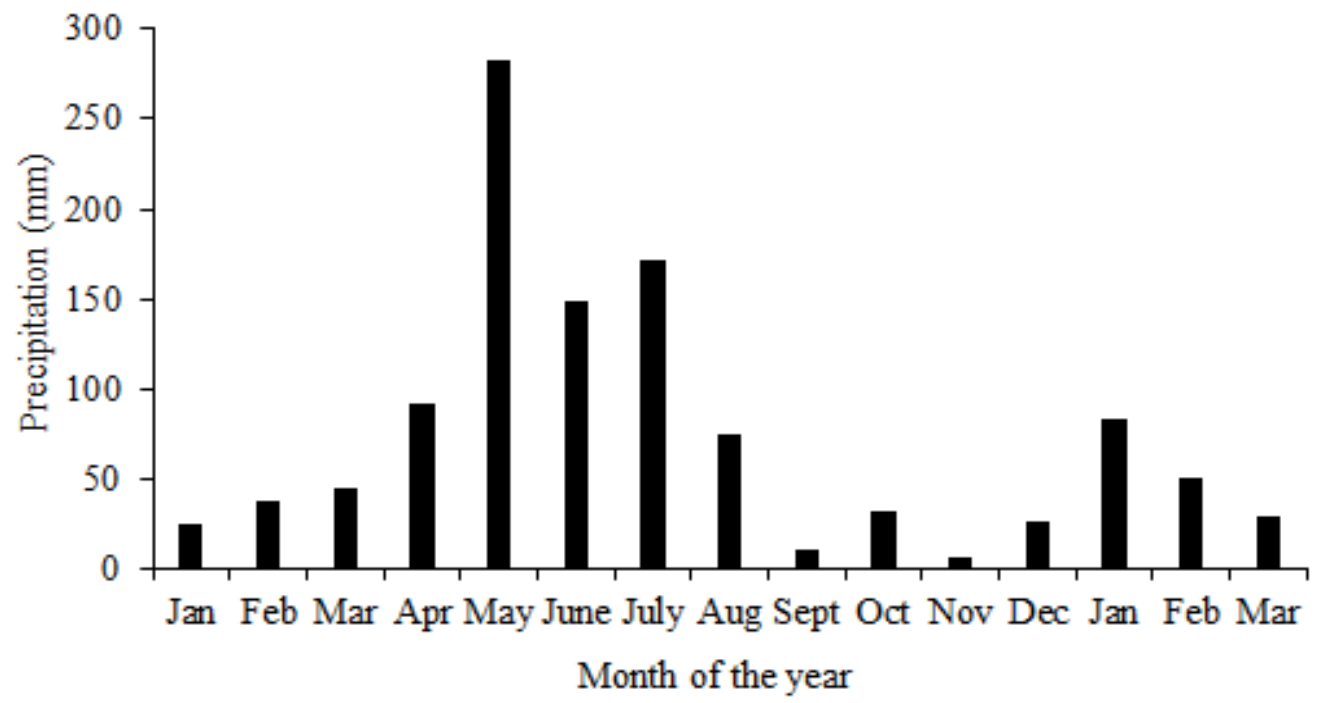

The experimental field was implemented in 2014 , in a $400-\mathrm{m}^{2}$ area, using seedlings. The soil in the area was classified as a Quartzarenic Neosol of clayey texture and flat relief. Soil analysis revealed the following properties: $\mathrm{pH}$ in water $=5.49 ; \mathrm{P}$ $\left(\right.$ Mehlich-1) $=3.90$ and $\mathrm{K}=138 \mathrm{mg} \mathrm{dm}^{-3} ; \mathrm{Ca}=$ $0.38 ; \mathrm{Mg}=0.35$ and $\mathrm{H}+\mathrm{Al}=1.24 ; \mathrm{SB}=1.21$, and $\mathrm{CEC}(\mathrm{pH} 7.0)=2.45 \mathrm{cmolc} \mathrm{dm}^{-3}$; and $\mathrm{OM}=11.8 \mathrm{~g}$ 
$\mathrm{dm}^{-3}$. Based on those results, the area was fertilized in September 2014, on a single occasion, with 100 $\mathrm{kg} \mathrm{ha}^{-1} \mathrm{P}_{2} \mathrm{O}_{5}$ as single superphosphate, $100 \mathrm{~kg} \mathrm{ha}^{-1}$ $\mathrm{K}_{2} \mathrm{O}$ as potassium chloride, and $60 \mathrm{~kg} \cdot \mathrm{ha}^{-1} \mathrm{~N}$ as ammonium sulfate.

Cultivation practices for the establishment of digit grass were performed from August to December 2015. Whenever the canopy reached an average height of $40 \mathrm{~cm}$, it was lowered to $10 \mathrm{~cm}$ via cutting. In January 2015, a uniformity cut was made to a residual height of $10 \mathrm{~cm}$ in all experimental units, marking the start of the experimental period. The experimental area was irrigated regularly throughout the entire experimental period so as to maintain field capacity at around 50\%. For this purpose, the soil moisture level was monitored daily using tensiometers. Whenever necessary, the grass was wet manually with water cans.

Four defoliation frequencies were tested, namely very high, high, medium, and low (cut made when the plant reached 25, 35, 45, and 55 $\mathrm{cm}$, respectively). On the said occasions, the plant was lowered to a post-cutting residual height of $10 \mathrm{~cm}$ (SOUZA et al., 2016), at two times of the year [greater insolation (September to March) and lesser insolation (April to August)]. The defoliation frequencies were allocated to the experimental units (4.6- $\mathrm{m}^{2}$ plots) in a randomized-block design with four replicates.

Maintenance fertilization was performed using $300 \mathrm{~kg}$ of $\mathrm{N} \mathrm{ha}^{-1}$ per year, as recommended by Souza et al. (2016), as ammonium sulfate, and $240 \mathrm{~kg}$ of $\mathrm{K} \mathrm{ha}^{-1}$ per year as potassium chloride. Fertilizer applications were split according to the cutting interval as proposed by Sousa et al. (2010), such that all plots would receive the same amount of fertilizer at the end of the experimental period. Fertilization was applied after each defoliation.

Height was measured at every seven days using a centimeter-graduated ruler, at five random points per experimental unit, as the distance between the soil and the leaf horizon. As the height approached the target established for defoliation, the measurement was taken at every two days.

The leaf area index (leaf, stem, and dead herbage) was measured when the canopy reached its defoliation height, using a Sun Scan canopy analyzer, at three points per experimental unit. At each point, one reading was taken above the canopy and one at the soil surface (within the canopy).

Herbage accumulation (kg ha ${ }^{-1}$ DM) was estimated by harvesting a sample of herbage at a residual height of $10 \mathrm{~cm}$ from within a $0.70-\mathrm{m}^{2}$ sampling frame that was thrown at random in each experimental unit. Samples were stored in identified plastic bags and then taken to the Laboratory of Forage Crops (LAFOR) at UFS, where they were weighed and sub-divided into two sub-samples. The first was divided into green leaves, stems, and dead herbage. After this separation, all components were packed in plastic bags, weighed, dried in a forced-air oven at $55^{\circ} \mathrm{C}$ for $72 \mathrm{~h}$, and then weighed again. The other sub-sample was weighed, dried in a forced-air oven at $55^{\circ} \mathrm{C}$ for $72 \mathrm{~h}$, and then weighed again.

The estimated accumulation rates of herbage $\left(\mathrm{kg} \mathrm{ha}^{-1}\right.$ day $\left.^{-1} \mathrm{DM}\right)$ and morphological components were calculated by dividing the accumulated total herbage and morphological components by the defoliation interval of each growth cycle. The volume density of herbage $\left(\mathrm{kg} \mathrm{ha}{ }^{-1} \mathrm{~cm}^{-1}\right)$ and morphological components was calculated by dividing the accumulated mass of herbage and morphological components (in DM) by the respective herbage removal height.

Total tiller density was determined by counting the number of basal and aerial tillers within a 0.23$\mathrm{m}^{2}$ sampling frame that was allocated at random to the experimental unit. The count was also made before cutting (moment when the canopy reached its defoliation height).

The data were organized into two periods of the year: greater insolation (September to March) and lesser insolation (April to August). The thus organized data were subjected to analysis of 
variance using the MIXED procedure of the SAS statistical package (Statistical Analysis System, version 8.2) for Windows. Akaike's information criterion was used in the choice of the variance and covariance matrix (WOLFINGER, 1993). In this way, it was possible to detect the effect of the main causes of variation (defoliation height and period of the year) and of the interaction between them. The effects of defoliation height, period of the year, and their interactions were considered fixed, whereas the block effect and its interactions were considered random (LITTELL et al., 2000). Means were estimated using the LSMEANS procedure and compared using Student's $t$ test at the 5\% significance level.

\section{Results and Discussion}

The defoliation heights were close to the target heights $(26.2 \mathrm{~cm}$ for the height of $25 \mathrm{~cm} ; 35.5 \mathrm{~cm}$ for the height of $35 \mathrm{~cm} ; 45.8 \mathrm{~cm}$ for the height of $45 \mathrm{~cm}$; and $54.4 \mathrm{~cm}$ for the height of $55 \mathrm{~cm}$ ). The cutting interval was influenced $(\mathrm{P}<0.05)$ by the defoliation heights and time of the year. The decreasing defoliation frequencies extended the interval between cuts (Figure 3). In the period of lesser insolation, digit grass had a longer cutting interval (37.0 days) than in the period of greater insolation (31.5 days).

Figure 3. Cutting interval of digit grass subjected to defoliation frequencies.

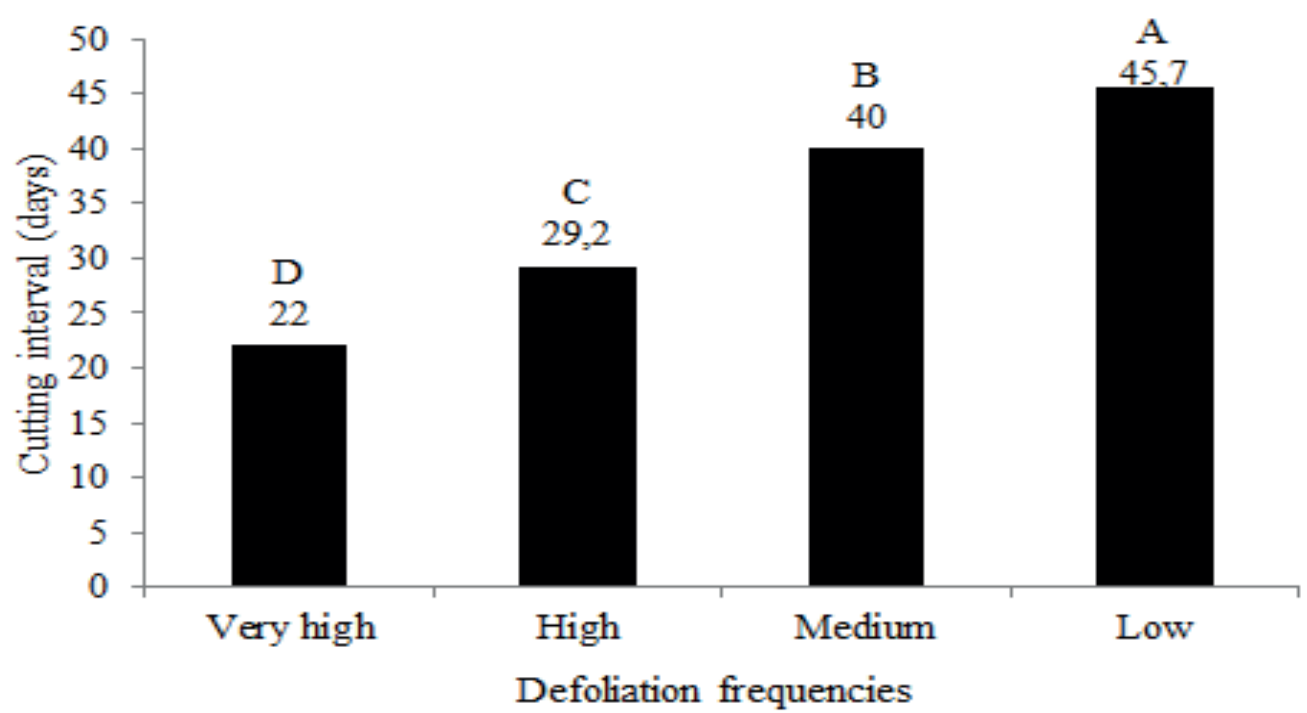

Means followed by the same letter do not differ according to Student's $t$ test $(\mathrm{P}>0.05)$.

Because the defoliations were performed to the same post-cutting residual height of $10 \mathrm{~cm}$, the plants took longer to reach greater heights, which led to longer cutting intervals. This behavior has also been described in the Marandu (DIFANTE et al., 2011), Mulato (SILVEIRA et al., 2013), Tanzania (EUCLIDES et al., 2014), Mombaça (EUCLIDES et al., 2015), and Aruana (SILVA et al., 2015a) grasses. These results reinforce the impossibility of using fixed and pre-determined rest days for the management of pastures, including digit grass. This is because the time necessary to achieve the established management target can vary according to forage species, adopted management strategy, time of the year, nutrient availability, farm location, among other factors (PEDREIRA et al., 2007). 
Total herbage accumulation and the accumulation rates of total herbage, leaves, and stems were influenced $(\mathrm{P}<0.05)$ by the interaction between defoliation frequency and period of the year. Total herbage accumulation and the accumulation rates of total herbage and stems rose as the defoliation frequency was reduced, irrespective of the time of the year. In the period of lesser insolation, there was a reduction in leaf accumulation rate as the defoliation frequency was reduced. In the period of greater insolation, total herbage accumulation and the accumulation rates of total herbage and leaves were higher than those obtained in the period of lesser insolation. Stem accumulation rate, in turn, was higher in the period of greater insolation in the canopies defoliated at the high, medium, and low frequencies (Table 1). Dead-herbage accumulation rate was influenced $(\mathrm{P}<0.05)$ by defoliation frequency and period of the year. The decreasing defoliation frequencies led to a reduction in deadherbage accumulation rate (Figure 4). The highest values for this variable were recorded in the period of lesser insolation (7.6 kg vs. $5.8 \mathrm{~kg} \mathrm{ha}^{-1}$ day $^{-1}$ in the period of greater insolation).

Table 1. Total herbage accumulation and total-herbage, leaf, and stem accumulation rates in digit grass subjected to defoliation frequencies in different periods of the year.

\begin{tabular}{|c|c|c|c|c|c|}
\hline \multirow{2}{*}{ Period } & \multicolumn{4}{|c|}{ Defoliation frequency } & \multirow{2}{*}{ SEM } \\
\hline & Very high & High & Medium & Low & \\
\hline \multicolumn{6}{|c|}{ Total herbage accumulation $\left(\mathrm{kg} \mathrm{ha}^{-1}\right)$} \\
\hline Greater insolation & $16,001 \mathrm{Ca}$ & $16,964 \mathrm{Ca}$ & $20,645 \mathrm{Ba}$ & $22,289 \mathrm{Aa}$ & 479.1 \\
\hline Lesser insolation & $9,500 \mathrm{Cb}$ & $9,940 \mathrm{Bb}$ & $10,058 \mathrm{Bb}$ & $10,452 \mathrm{Ab}$ & 83.4 \\
\hline \multicolumn{6}{|c|}{ Total herbage accumulation rate $\left(\mathrm{kg} \mathrm{ha}^{-1} \mathrm{day}^{-1}\right)$} \\
\hline Greater insolation & $70.3 \mathrm{Ca}$ & $75.1 \mathrm{Ca}$ & $92.2 \mathrm{Ba}$ & $100.5 \mathrm{Aa}$ & 2.31 \\
\hline Lesser insolation & $62.5 \mathrm{Cb}$ & $65.4 \mathrm{Bb}$ & $66.1 \mathrm{Bb}$ & $68.7 \mathrm{Ab}$ & 0.54 \\
\hline \multicolumn{6}{|c|}{ Leaf accumulation rate $\left(\mathrm{kg} \mathrm{ha}^{-1} \mathrm{day}^{-1}\right)$} \\
\hline Greater insolation & $48.0 \mathrm{Aa}$ & $48.4 \mathrm{Aa}$ & 45.4 Aa & $46.3 \mathrm{Aa}$ & 1.44 \\
\hline Lesser insolation & $41.3 \mathrm{Ab}$ & $41.2 \mathrm{Ab}$ & $33.2 \mathrm{Bb}$ & $31.8 \mathrm{Cb}$ & 0.36 \\
\hline \multicolumn{6}{|c|}{ Stem accumulation rate $\left(\mathrm{kg} \mathrm{ha}^{-1} \mathrm{day}^{-1}\right)$} \\
\hline Greater insolation & $18.1 \mathrm{Ca}$ & $22.9 \mathrm{Ca}$ & $39.7 \mathrm{Ba}$ & $46.1 \mathrm{Aa}$ & 1.58 \\
\hline Lesser insolation & $15.4 \mathrm{Da}$ & $18.9 \mathrm{Cb}$ & $23.5 \mathrm{Bb}$ & $26.8 \mathrm{Ab}$ & 0.24 \\
\hline
\end{tabular}

For each trait, means followed by the same uppercase letter in the row and lowercase letter in the column do not differ according to Student's t test $(\mathrm{P}>0.05)$. ${ }^{1} \mathrm{SEM}=$ standard error of the mean. 
Figure 4. Dead-herbage accumulation rate of digit grass subjected to defoliation frequencies.

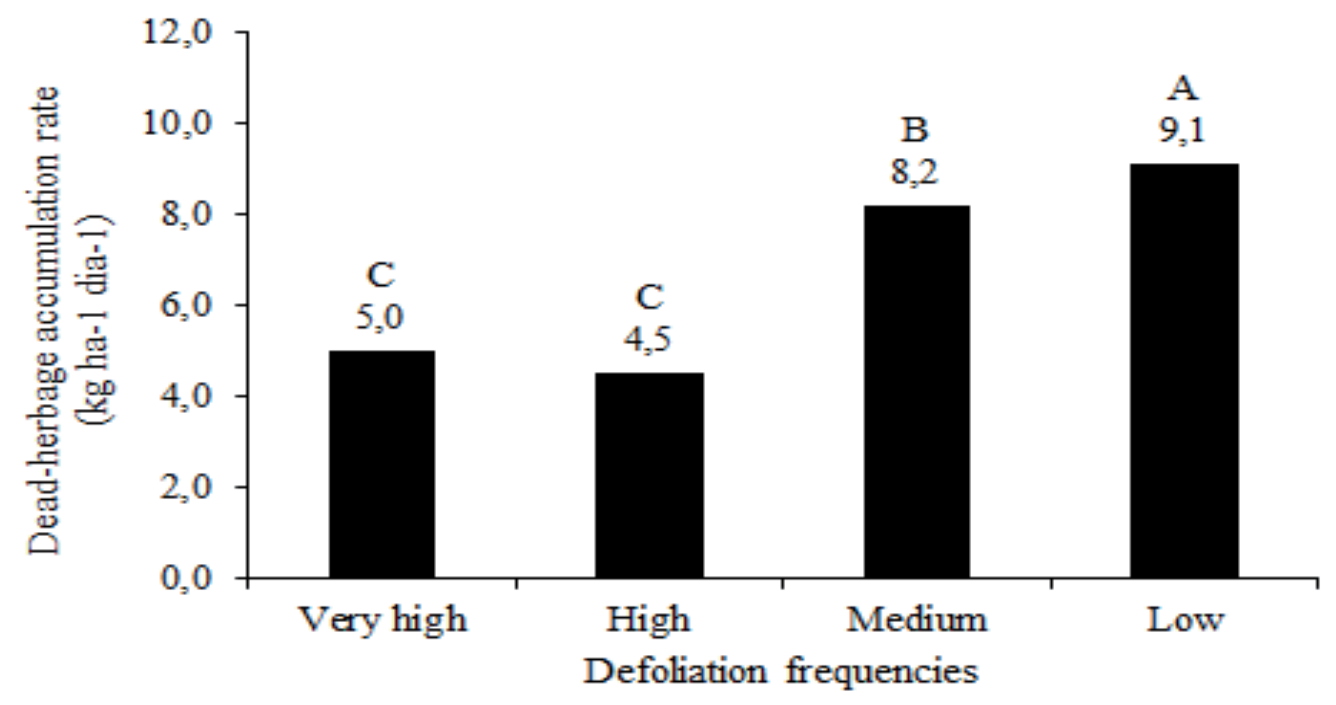

Means followed by the same lëttêr do not differ according to Student's t test $(\mathrm{P}>0.05)$.

At the start of regrowth, forage plants accumulate leaf blades, mainly (CARNEVALLI et al., 2006), in an attempt to reestablish the photosynthetic capacity of the canopy after defoliation. As the plant grows, the intraspecific competition for light within the canopy is accentuated, modifying its growth pattern (SILVA; NASCIMENTO JÚNIOR, 2007). The reduction in quantity and quality of light that penetrates taller canopies (BARBOSA et al., 2007; PEDREIRA et al., 2007) reduces the leaf accumulation rate and increases the stem and dead-herbage accumulation rates, as was observed in the current study (Table 1). Despite the reduction of leaf accumulation rate, there was an elevation in the stem and dead-herbage accumulation rates, which certainly led to the larger total herbage accumulations in the taller canopies. It should also be stressed that although it was frequently defoliated, digit grass exhibited high herbage accumulation rates (higher than $20 \mathrm{t} \mathrm{ha}^{-1}$ year ${ }^{-1}$ ), demonstrating the great productive potential of this forage plant when properly irrigated and managed.
The percentage of leaves was influenced $(\mathrm{P}<0.05)$ only by the defoliation frequency. The decreasing defoliation heights reduced the percentage of leaf (Figure 5). The percentages of stems and dead herbage were influenced $(\mathrm{P}<0.05)$ by the interaction between defoliation frequency and period of the year (Table 2). Regardless of the time of the year, the reduction of defoliation frequency elevated the percentage of stem. The digit grass defoliated at 45 and $55 \mathrm{~cm}$ in the period of greater insolation showed a higher percentage of stem than in the period of lesser insolation. The percentage of dead herbage was higher when the grass was defoliated at the heights of 45 and $55 \mathrm{~cm}$ than at 25 and $35 \mathrm{~cm}$, irrespective of the time of the year. In the period of greater luminosity, the canopy showed a higher percentage of dead herbage than in the period of lesser luminosity, independent of the defoliation height (Table 2). 
Figure 5. Percentage of leaves in digit grass subjected to defoliation frequencies.

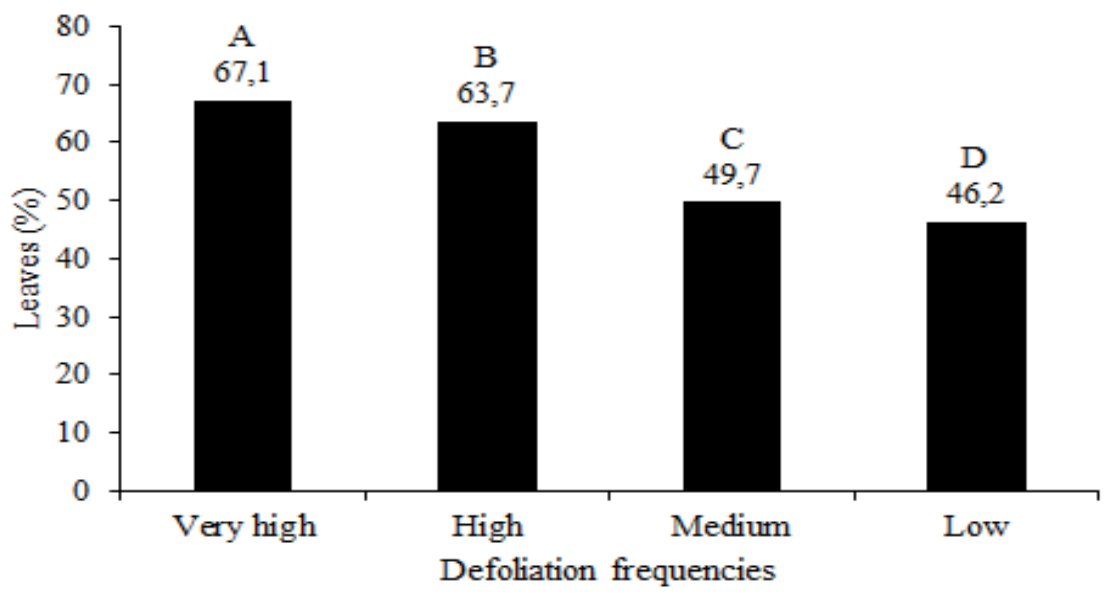

Means followed by the same letter do not differ according to Student's $t$ test $(\mathrm{P}>0.05)$.

Table 2. Percentages of stem and dead herbage in digit grass subjected to defoliation frequencies in different periods of the year.

\begin{tabular}{cccccc}
\hline \multirow{2}{*}{ Period } & \multicolumn{4}{c}{ Defoliation frequency } & \multirow{2}{*}{ SEM $^{1}$} \\
\cline { 2 - 4 } & Very high & High & Medium & Low & \\
\hline \multirow{3}{*}{ Greater insolation } & $25.6 \mathrm{Ca}$ & Stem (\%) & & \\
Lesser insolation & $24.6 \mathrm{Da}$ & $28.9 \mathrm{Ca}$ & $42.9 \mathrm{Aa}$ & $45.8 \mathrm{Aa}$ & 0.97 \\
& & $35.5 \mathrm{Bb}$ & $39.0 \mathrm{Ab}$ & 0.33 \\
Greater insolation & $6.0 \mathrm{Bb}$ & $5.1 \mathrm{Bb}$ & $7.7 \mathrm{Ab}$ & $8.0 \mathrm{Ab}$ & 0.48 \\
Lesser insolation & $9.3 \mathrm{Ba}$ & $8.0 \mathrm{Ba}$ & $14.2 \mathrm{Aa}$ & $14.7 \mathrm{Aa}$ & 0.48 \\
\hline
\end{tabular}

For reach trait, means followed by the same uppercase letter in the row and lowercase letter in the column do not differ according to Student's t test $(\mathrm{P}>0.05)$. ${ }^{1} \mathrm{SEM}=$ standard error of the mean.

Although digit grass showed higher herbage accumulation rates at the lower defoliation frequencies (Table 1), it can be inferred that this forage is lower quality, since the percentage of leaves in it decreased (Figure 5) and the percentages of stem and dead herbage increased (Table 2). Leaves are preferred by grazing animals because they have a higher protein content and are more digestible than stems (PALHANO et al., 2005, 2007). Moreover, the stem and the leaf sheath are a physical limitation to herbage intake by grazing animals, which can reduce the bite depth and herbage intake. Therefore, despite the higher herbage accumulation rate, the larger proportion of stems and dead herbage in the canopy can change the nutritional value of the diet and hamper the capture of feed by the grazing animal (PALHANO et al., 2007; VOLTOLINI et al., 2010a, b).

It is noteworthy, however, that the stems in this plant are thin and flexible when green, which may make this component less limiting to intake by grazing animals. Thus, further studies should be carried out with grazing animals to validate these inferences for digit grass.

The total-herbage and leaf volume densities were affected $(\mathrm{P}<0.05)$ by the defoliation frequencies and periods of the year. Higher total-herbage 
volume densities were recorded when the grass was defoliated at 25 and $55 \mathrm{~cm}$. Leaf volume density declined as the defoliation frequency was reduced (Figure 6). In the period of greater insolation, higher total-herbage $\left(96.1 \mathrm{~kg} \mathrm{ha}^{-1} \mathrm{~cm}^{-1}\right)$ and leaf $\left(55.1 \mathrm{~kg} \mathrm{ha}^{-1} \mathrm{~cm}^{-1}\right)$ volume densities were recorded in comparison with the period of lesser insolation (78.3 and $44.3 \mathrm{~kg} \mathrm{ha}^{-1} \mathrm{~cm}^{-1}$ ), respectively.

Figure 6. Total-herbage and leaf volume densities in digit grass subjected to defoliation frequencies at different times of the year.

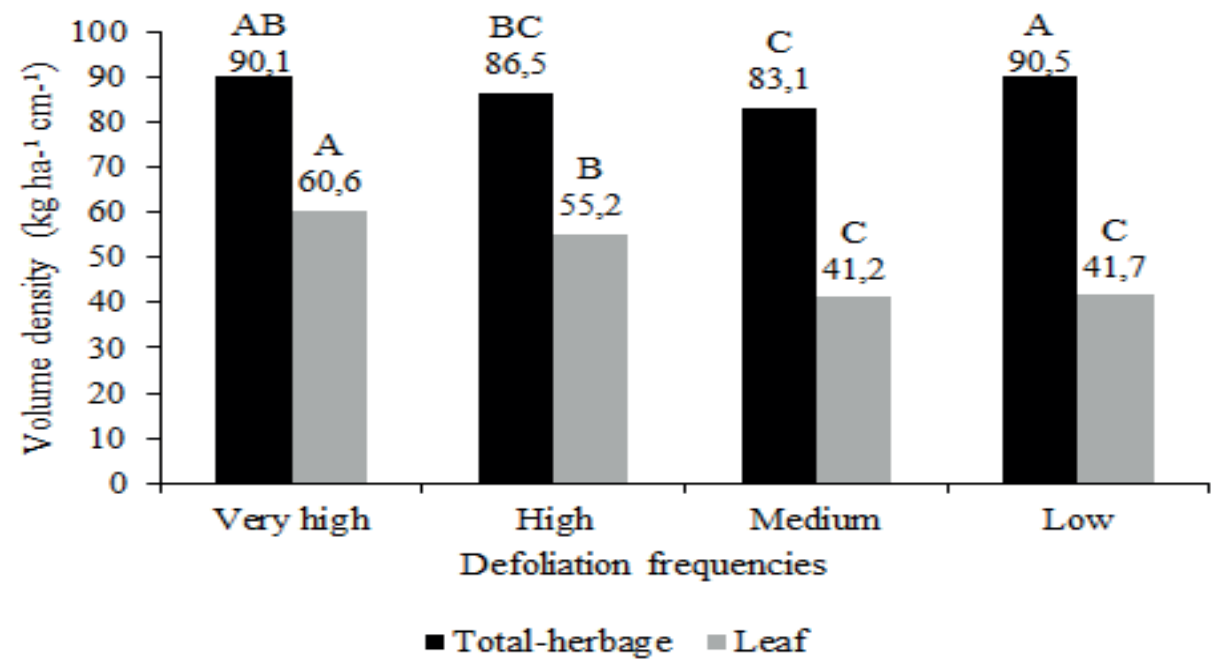

For each trait, means followed by the same letter do not differ according to Student's t test $(\mathrm{P}>0.05)$.

The stem and dead-herbage volume densities were influenced $(\mathrm{P}<0.05)$ by the interaction between defoliation frequency and period of the year. In the period of greater insolation, the canopies defoliated at the heights of 25 and $35 \mathrm{~cm}$ obtained lower stem and dead-herbage volume densities. Dead-herbage volume density decreased when the defoliation height was raised from 25 to $35 \mathrm{~cm}$, but increased thereafter. In the period of greater isolation, there was a higher stem volume density and a lower deadherbage volume density (Table 3 ).

Table 3. Stem and dead-herbage volume density $\left(\mathrm{kg} \mathrm{ha}^{-1} \mathrm{~cm}^{-1}\right)$ in digit grass subjected to defoliation frequencies in different periods of the year.

\begin{tabular}{|c|c|c|c|c|c|}
\hline \multirow{2}{*}{ Period } & \multicolumn{4}{|c|}{ Defoliation frequency } & \multirow{2}{*}{$\mathrm{SEM}^{1}$} \\
\hline & Very high & High & Medium & Low & \\
\hline \multicolumn{6}{|c|}{ Stem volume density $\left(\mathrm{kg} \mathrm{ha}^{-1} \mathrm{~cm}^{-1}\right)$} \\
\hline Greater insolation & $24.7 \mathrm{Ba}$ & $29.4 \mathrm{Ba}$ & $40.9 \mathrm{Aa}$ & $45.5 \mathrm{Aa}$ & 1.58 \\
\hline Lesser insolation & $20.6 \mathrm{Ca}$ & $22.1 \mathrm{Cb}$ & $25.2 \mathrm{Bb}$ & $31.9 \mathrm{Ab}$ & 0.51 \\
\hline \multicolumn{6}{|c|}{ Dead-herbage volume density $\left(\mathrm{kg} \mathrm{ha}^{-1} \mathrm{~cm}^{-1}\right)$} \\
\hline Greater insolation & $5.9 \mathrm{Bb}$ & $5.8 \mathrm{Ba}$ & $7.3 \mathrm{Ab}$ & $7.5 \mathrm{Ab}$ & 0.40 \\
\hline Lesser insolation & 7.7 Ca & $6.1 \mathrm{Da}$ & $10.1 \mathrm{Ba}$ & $12.0 \mathrm{Aa}$ & 0.40 \\
\hline
\end{tabular}

For each trait, means followed by the same uppercase letter in the row and lowercase letter in the column do not differ according to Student's t test $(\mathrm{P}>0.05)$.

${ }^{1} \mathrm{SEM}=$ standard error of the mean. 
Overall, the decrease in defoliation frequency reduced leaf volume density and increased the stem and dead-herbage volume densities. These responses are very similar to those shown by the accumulation rates of leaf, stem (Table 1), and dead herbage (Figure 4). In the analysis of the variations in leaf, stem, and dead-herbage volume densities combined, based on the total-herbage volume density, it is observed that variations in the heights of digit grass lead to changes in canopy structure. In this way, in this experiment, the defoliation heights reduced the volume density of digit grass up to $45 \mathrm{~cm}$, subsequently increasing at the height of $55 \mathrm{~cm}$. The reduction in volume density of leaf, stem, and dead herbage was possibly because the increase in defoliation height was not proportional to the increase in accumulation of these components (SANTOS et al., 2010a, b). The reduction of total volume density up to $45 \mathrm{~cm}$ of height is a result of the increase in canopy height that was equivalent to that of total herbage mass. However, the increase in total herbage volume density at the height of $55 \mathrm{~cm}$ can be explained by the increased participation of stem volume density (Table 3 ). Therefore, volume density alters the feeding behavior of grazing animals, modifying their bite rate, time per bite, and, consequently, grazing time (PALHANO et al., 2007; TRINDADE et al., 2007; DIFANTE et al., 2009).

Total tiller density was influenced $(\mathrm{P}<0.05)$ by the interaction between defoliation frequency and period of the year. In the period of greater insolation, higher total tiller density values were recorded in the canopies defoliated at 25 and 35 $\mathrm{cm}$ than in those defoliated at 45 and $55 \mathrm{~cm}$. In the period of lesser insolation, however, the increasing defoliation heights resulted in decreased total tiller density. Irrespective of the defoliation height, the higher total tiller densities values recorded in the period of greater insolation (Table 4).

Table 4. Total tiller density (tillers $\mathrm{m}^{-2}$ ) of digit grass subjected to defoliation frequencies in different periods of the year.

\begin{tabular}{cccccc}
\hline \multirow{2}{*}{ Period } & \multicolumn{3}{c}{ Defoliation frequency } & \multicolumn{2}{c}{ SEM $^{1}$} \\
\cline { 2 - 5 } & Very high & High & Mean & Low & 18.2 \\
Greater insolation & $1.009 \mathrm{Aa}$ & $953 \mathrm{Aa}$ & $760 \mathrm{Ba}$ & $725 \mathrm{Ba}$ & \\
Lesser insolation & $781 \mathrm{Ab}$ & $757 \mathrm{ABb}$ & $702 \mathrm{Bb}$ & $618 \mathrm{Cb}$ & 18.2 \\
\hline
\end{tabular}

Means followed by the same uppercase letter in the row and lowercase letter in the column do not differ according to Student's $\mathrm{t}$ test $(\mathrm{P}>0.05) .{ }^{1} \mathrm{SEM}=$ standard error of the mean.

Indeed, the decreasing total tiller density observed with the reduction of defoliation frequency is a consequence of competition for light. Overall, the canopy of taller pastures intercepts more light, which means greater intraspecific competition for light (SILVA; NASCIMENTO JÚNIOR, 2007). This greater competition for light increases the senescence and death of tillers in a mechanism described as size/density compensation (MARTÍNEZ CALSINA et al., 2012; MATTHEW et al., 1995; SBRISSIA; SILVA, 2008). In this way, shorter pastures have a higher tiller density, while taller pastures have a lower tiller density. Shorter canopies intercept more light in both quantity and quality, which can stimulate the activation of axillary buds capable of generating a new tiller and increasing their population density (SACKVILLE HAMILTON et al., 1995; DIFANTE et al., 2011)

The leaf area index was influenced $(\mathrm{P}<0.05)$ by the interaction between defoliation frequency and period of the year. Irrespective of the period, 
the decreasing defoliation frequency resulted in a higher leaf area index. The digit grass defoliated at
25 and $35 \mathrm{~cm}$ had a higher leaf area index in the period of lesser insolation (Figure 7).

Figure 7. Leaf area index of digit grass subjected to defoliation frequencies.

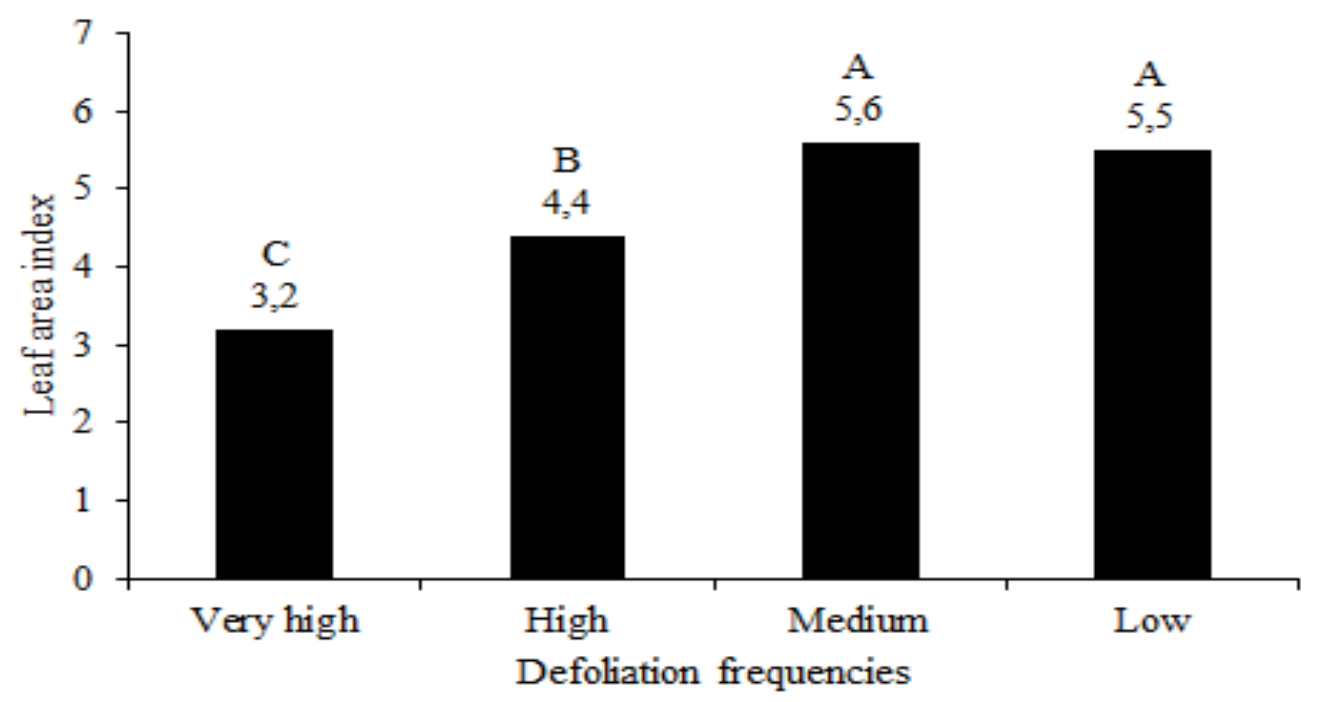

Means followed by the same letter do not differ according to Student's t test $(\mathrm{P}>0.05)$.

The leaf area index is determined by structural characteristics of the forage canopy (LEMAIRE; CHAPMAN, 1996; SILVA; NASCIMENTO JÚNIOR, 2007; BARBERO et al., 2015) such as final leaf length, number of live leaves, tiller density, and leaf-to-stem ratio. Thus, throughout regrowth, as the plant grows and recovers its leaf area, its light interception increases in an attempt to reestablish its photosynthetic capacity (SILVA; NASCIMENTO JÚNIOR, 2007), reaching a maximum value. In the case of digit grass, the increasing defoliation heights elevated the leaf area index (leaves, stems, and dead herbage) until the height of $45 \mathrm{~cm}$, after which this variable remained constant. In the current study, although the increasing defoliation heights reduced the total tiller density (Table 4), leaf area index rose. This reduction in total tiller density was likely compensated by the existence of tillers with longer and ticker leaves and or with a larger number of live leaves as well as a higher leaf-to-stem ratio, as reported by Lemaire and Chapman (1996) and Silva and Nascimento Júnior (2007).
Overall, total herbage accumulation and the accumulation rates of total herbage, leaf blade, and stem (Table 1) as well as the percentages of stem and dead herbage at the highest defoliation heights and total tiller density were higher and dead-herbage accumulation rate was lower in the period of lesser insolation. As a consequence, the defoliation interval (Figure 3) decreased in the period of greater insolation in response to the greater growth rate of the forage plant. According to Silva and Nascimento Júnior (2007) and Silva et al. (2015b), both the resources provided by the environment (water, light, temperature, nutrients) and the management practices (frequency and intensity of defoliation, fertilization) affect the development of forage plants. In the present study, water availability was probably not limiting to the growth of digit grass between the periods of the year, since the experimental units were irrigated during the experimental period. However, there was a variation in the availability of other factors such as luminosity and temperature (Figure 1). The 
period of lesser insolation in Sergipe coincides with the rainy period, when the average temperatures are lower and luminosity is reduced (Figures 1 and 2) due to the occurrence of shorter days and cloudy days. By contrast, higher average temperatures and luminosity were recorded in the period of greater insolation, which might have increased the growth of digit grass, contributing for it to reach its defoliation height in less time. Duru and Ducrocq (2000) recorded higher leaf appearance rates in Dactylis glomerata L. Lude in periods of higher insolation and temperatures.

\section{Conclusions}

Less frequent defoliations increase the herbage accumulation rate of digit grass, but lead to a less desirable morphological composition. Digit grass should be defoliated upon reaching $45 \mathrm{~cm}$ in height. Digit grass has great productive potential when irrigated and managed adequately.

\section{Acknowledgments}

This study was financed in part by the Coordenação de Aperfeiçoamento de Pessoal de Nível Superior - Brasil (CAPES) - Finance Code 001, and also Conselho Nacional de Desenvolvimento Científico e Tecnológico (CNPq) and Fundação de Apoio à Pesquisa e à Inovação Tecnológica do Estado de Sergipe (FAPITEC).

\section{References}

ARONOVICH, S.; CASTAGNA, A. A.; ARONOVICH, M. Potencial das gramíneas do gênero Digitaria para produção animal na Região Sudeste do Brasil. Pesquisa Agropecuária Brasileira, Brasília, v. 31, n. 11, p. 829834, 1996.

BARBERO, L. M.; BASSO, K. C.; IGARASI, M. S.; PAIVA, A. J.; BASSO, F. C. Respostas morfogênicas e estruturais de plantas tropicais submetidas à desfolhação. Boletim de Indústria Animal, Nova Odessa, v. 72, n. 4, p. 321-330, 2015.
BARBOSA, R. A.; NASCIMENTO JÚNIOR, D. D.; EUCLIDES, V. P. B.; SILVA, S. D.; ZIMMER, A. H.; TORRES JÚNIOR, R. D. A. Capim-tanzânia submetido a combinações entre intensidade e frequência de pastejo. Pesquisa Agropecuária Brasileira, Brasília, v. 42, n. 3, p. 329-340, 2007.

CARNEVALLI, R.; SILVA, S. da; BUENO, A. D. O.; UEBELE, M.; BUENO, F.; HODGSON, J.; SILVA, G.; MORAIS, J. Herbage production and grazing losses in Panicum maximum cv. Mombaça under four grazing managements. Tropical Grasslands, Cali, v. 40, n. 3, p. 165-176, 2006.

DIFANTE, G. D. S.; EUCLIDES, V.P. B.; NASCIMENTO JÚNIOR, D. D.; SILVA, S. C. D.; TORRES JÚNIOR, R. A. D. A.; SARMENTO, D. O. D. L. Ingestive behaviour, herbage intake and grazing efficiency of beef cattle steers on Tanzania guineagrass subjected to rotational stocking managements. Revista Brasileira de Zootecnia, Viçosa, v. 38, n. 6, p. 1001-1008, 2009.

DIFANTE, G. D. S.; NASCIMENTO JÚNIOR, D. do; SILVA, S. C. da; EUCLIDES, V. P. B.; MONTAGNER, D. B. Características morfogênicas e estruturais do capim-marandu submetido a combinações de alturas e intervalos de corte. Revista Brasileira de Zootecnia, Viçosa, v. 40, n. 5, p. 955-963, 2011.

DURU, M.; DUCROCQ, H. Growth and senescence of the successive grass leaves on a tiller. Ontogenic development and effect of temperature. Annals of Botany, Oxford, v. 85, n. 5, p. 635-643, 2000.

EUCLIDES, V. P. B.; LOPES, F. C.; NASCIMENTO JUNIOR, D.; SILVA, S. C. da; DIFANTE, G. D. S.; BARBOSA, R. A. Steer performance on Panicum maximum (cv. Mombaça) pastures under two grazing intensities. Animal Production Science, Camberra, v. 56, n. 11, p. 1849-1856, 2015.

EUCLIDES, V. P. B.; MONTAGNER, D. B.; DIFANTE, G. D. S.; BARBOSA, R. A.; FERNANDES, W. S. Sward structure and livestock performance in guinea grass cv. Tanzania pastures managed by rotational stocking strategies. Scientia Agricola, Piracicaba, v. 71, n. 6, p. 451-457, 2014.

GARCÍA, G.; PÉREZ, G. Uso y manejo de pastizales em la cria intensiva de ovinos y caprinos. In: URDANETA, L. C. D.; MILANO, G. M. (Ed.). Manual de producción de caprinos y ovinos. Barquisimeto: INIA - Instituto Nacional de Investigaciones Agrrícolas, 2005. p. 105116.

LEMAIRE, G.; CHAPMAN, D. Tissue flows in grazed plant communities. In: HODGSON, J.; ILLIUS, A. W. (Eds.) The ecology and management of grazing systems. 
Wallingford: CAB International, 1996. p. 3-36.

LITTELL, R. C.; PENDERGAST, J.; NATARAJAN, R. Tutorial in biostatistics: modelling covariance structure in the analysis of repeated measures data. Statistics in Medicine, Hudson, v. 19, n. 13, p. 1793-1819, 2000.

MARTÍNEZ CALSINA, L.; AGNUSDEI, M.; ASSUERO, S.; PÉREZ, H. Size/density compensation in Chloris gayana Kunth cv. Fine Cut subjected to different defoliation regimes. Grass and Forage Science, Oxford, v. 67, n. 2, p. 255-262, 2012.

MATTHEW, C.; LEMAIRE, G.; HAMILTON, N. S.; HERNANDEZ-GARAY, A. A modified self-thinning equation to describe size/density relationships for defoliated swards. Annals of Botany, Oxford, v. 76, n. 6, p. 579-587, 1995.

NAVARRO, D.; RODRÍGUEZ, P.; GONZÁLEZ, C.; TORRES, D. Umfolozi o pangola peluda: un pasto que comienza a ser cultivado. In: RENGIFO, C.; PÉREZ, E.; SANTOS, A. R. (Ed.). Revista de difusión de tecnología agrícola, pecuaria, pesquera y acuícola. Aragua: INIAInstituto Nacional de Investigaciones Agrícolas, 2005. p. 29-32.

OLIVEIRA, V. S.; MORAIS, J. A. D. S.; FAGUNDES, J. L.; SANTANA, J. C. D. S.; LIMA, I. G. S.; SANTOS, C. B. Produção e composição químico-bromatológica de gramíneas tropicais submetidas a dois níveis de irrigação. Archives of Veterinary Science, Curitiba, v. 20, n. 2, p. 27-36, 2015.

PALHANO, A. L.; CARVALHO, P. C. F.; DITTRICH, J. R.; MORAES, A.; BARRETO, M. Z.; SANTOS, M. C. F. Estrutura da pastagem e padrões de desfolhação em capim-mombaça em diferentes alturas do dossel forrageiro. Revista Brasileira de Zootecnia, Viçosa, MG, v. 34, n. 6, p. 1860-1870, 2005.

PALHANO, A. L.; CARVALHO, P. C. F.; DITTRICH, J. R.; MORAES, A.; SILVA, S. C.; MONTEIRO, A. L. G. Características do processo de ingestão de forragem por novilhas holandesas em pastagens de capim-mombaça. Revista Brasileira de Zootecnia, Viçosa, MG, v. 36, n. 4, p. 1014-1021, 2007.

PEDREIRA, B. C.; PEDREIRA, C. G. S.; SILVA, S. $\mathrm{C}$ da. Estrutura do dossel e acúmulo de forragem de Brachiaria brizantha cultivar Xaraés em resposta a estratégias de pastejo. Pesquisa Agropecuária Brasileira, Brasília, v. 42, n. 2, p. 281-287, 2007.

SACKVILLE HAMILTON, N.; MATTHEW, C.; LEMAIRE, G. In defence of the $-3 / 2$ boundary rule: a reevaluation of self-thinning concepts and status. Annals of Botany, Oxford, v. 76, n. 6, p. 569-577, 1995.
SANTOS, M. E. R.; FONSECA, D. M.; SILVA, G. P.; PIMENTEL, R. M.; CARVALHO, V. V.; SILVA, S. P. Estrutura do pasto de capim-braquiária com variação de alturas. Revista Brasileira de Zootecnia, Viçosa, MG, v. 39 , n. 10, p. 2125-2131, 2010a.

SANTOS, M. E. R.; FONSECA, D. M.; SILVA, S. P.; CARVALHO, V. V.; PIMENTEL, R. M.; ALBINO, R. L. Características estruturais do pasto de capim-braquiária de acordo com a localização das fezes. Revista Brasileira de Zootecnia, Viçosa, v. 39, n. 10, p. 2116-2124, 2010 b.

SBRISSIA, A. F.; SILVA, S. C. da. Compensação tamanho/densidade populacional de perfilhos em pastos de capim-marandu. Revista Brasileira de Zootecnia, Viçosa, v. 37, n. 1, p. 35-47, 2008.

SILVA, L. V. D.; CÂNDIDO, M. J. D.; PESSOA, J. P. M.; CAVALCANTE, A. C. R.; SOUZA CARNEIRO, M. S. de; NASCIMENTO SILVA, A. do. Componentes da biomassa e características estruturais em capim-aruana sob diferentes frequências e intensidades de desfolhação. Pesquisa Agropecuária Brasileira, Brasília, v. 50, n. 12, p. 1192-1200, 2015a.

SILVA, S. C. da; NASCIMENTO JÚNIOR, D. D. Avanços na pesquisa com plantas forrageiras tropicais em pastagens: características morfofisiológicas e manejo do pastejo. Revista Brasileira de Zootecnia, Viçosa, v. 36, p. 122-138, 2007. Suplemento Especial.

SILVA, S. C. da; SBRISSIA, A. F.; PEREIRA, L. E. T. Ecophysiology of C4 forage grasses understanding plant growth for optimising their use and management. Agriculture, Basel, v. 5, n. 3, p. 598-625, 2015 b.

SILVEIRA, M. C. T. D.; SILVA, S. C. D.; SOUZA JÚNIOR, S. J. D.; BARBERO, L. M.; RODRIGUES, C. S.; LIMÃO, V. A.; PENA, K. D. S.; NASCIMENTO JÚNIOR, D. D. Herbage accumulation and grazing losses on Mulato grass subjected to strategies of rotational stocking management. Scientia Agricola, Piracicaba, v. 70, n. 4, p. 242-249, 2013.

SOUSA, B. M. D. L.; NASCIMENTO JÚNIOR, D. do; SILVA, S. C. da; FONSECA, M. C. T. D. S.; SBRISSIA, A. F. Morphogenetic and structural characteristics of andropogon grass submitted to different cutting heights. Revista Brasileira de Zootecnia, Viçosa, v. 39, n. 10, p. 2141-2147, 2010.

SOUZA, L. J. N.; SANTOS, D. B. O.; FAGUNDES, J. L.; SOUSA, B. M. D. L.; BACKES, A. A.; OLIVEIRA JÚNIOR, L. G. F.; SANTOS, A. D. F.; MOREIRA, A. L. Morfogênese do capim faixa-braca submetido a adubação nitrogenada. Boletim de Indústria Animal, Nova Odessa, v. 73, n. 4, p. 281-289, 2016. 
TRINDADE, J. D.; SILVA, S. C. da; SOUZA JÚNIOR, S. D.; GIACOMINI, A. A.; ZEFERINO, C. V.; GUARDA, V. D. A.; CARVALHO, P. D. F. Composição morfológica da forragem consumida por bovinos de corte durante o rebaixamento do capim-marandu submetido a estratégias de pastejo rotativo. Pesquisa Agropecuária Brasileira, Brasília, v. 42, n. 6, p. 883-890, 2007.

VOLTOLINI, T. V.; PORTELA SANTOS, F. A.; MARTINEZ, J. C.; IMAIZUMI, H.; CLARINDO, R. L.; PENATI, M. A. Produção e composição do leite de vacas mantidas em pastagens de capim-elefante submetidas a duas frequências de pastejo. Revista Brasileira de Zootecnia, Viçosa, v. 39, n. 1, p. 121-127, 2010a.

VOLTOLINI, T. V.; SANTOS, F. A. P.; MARTINEZ, J. C.; CLARINDO, R. L.; PENATI, M. A.; IMAIZUMI,
H. Características produtivas e qualitativas do capimelefante pastejado em intervalo fixo ou variável de acordo com a interceptação da radiação fotossinteticamente ativa. Revista Brasileira de Zootecnia, Viçosa, v. 39, n. 5, p. 1002-1010, 2010b.

WOLFINGER, R. Covariance structure selection in general mixed models. Communications in StatisticsSimulation and Computation, Philadelphia, v. 22, n. 4, p. 1079-1106, 1993.

ZANINE, A. D. M.; NASCIMENTO JÚNIOR, D. do; ROZALINO, M. E.; SANTOS, K. D. S. P.; SILVA, S. C. da; SBRISSIA, A. F. Características estruturais e acúmulo de forragem em capim-tanzânia sob pastejo rotativo. Revista Brasileira de Zootecnia, Viçosa, v. 40, n. 11, p. 2364-2373, 2011. 